\title{
Detection and Projections of Climate Change in Rio de Janeiro, Brazil
}

\author{
Claudine Dereczynski ${ }^{1}$, Wanderson Luiz Silva ${ }^{1}$, Jose Marengo ${ }^{2}$ \\ ${ }^{1}$ Department of Meteorology, Federal University of Rio de Janeiro, Rio de Janeiro, Brazil \\ ${ }^{2}$ Center for Earth System Science, National Institute for Space Research, Cachoeira Paulista, Brazil \\ Email: claudine@acd.ufrj.br,wanderson@ufrj.br, jose.marengo@inpe.br
}

Received November 29, 2012; revised January 2, 2013; accepted January 9, 2013

\begin{abstract}
A study on the detection and future projection of climate change in the city of Rio de Janeiro is here presented, based on the analysis of indices of temperature and precipitation extremes. The aim of this study is to provide information on observed and projected extremes in support of studies on impacts and vulnerability assessments required for adaptation strategies to climate change. Observational data from INMET's weather stations and projections from INPE's EtaHadCM3 regional model are used. The observational analyses indicate that rainfall amount associated with heavy rain events is increasing in recent years in the forest region of Rio de Janeiro. An increase in both the frequency of occurrence and in the rainfall amount associated with heavy precipitation are projected until the end of the 21 st Century, as are longer dry periods and shorter wet seasons. In regards to temperature, a warming trend is noted (both in past observations and future projections), with higher maximum air temperature and extremes. The average change in annual maximum (minimum) air temperatures may range between $2^{\circ} \mathrm{C}$ and $5^{\circ} \mathrm{C}\left(2^{\circ} \mathrm{C}\right.$ and $\left.4^{\circ} \mathrm{C}\right)$ above the current weather values in the late 21st Century. The warm (cold) days and nights are becoming more (less) frequent each year, and for the future climate (2100) it has been projected that about $40 \%$ to $70 \%$ of the days and $55 \%$ to $85 \%$ of the nights will be hot. Additionally, it can be foreseen that there will be no longer cold days and nights.
\end{abstract}

Keywords: Climate Change; Extreme Event Indices; Air Temperature; Precipitation; Eta-HadCM3 Model; Rio de Janeiro

\section{Introduction}

The changes occurring in the climate extremes, such as an increase in hot days, decrease in cold days, longer heat waves or more frequent intense rains or severe drought, have a major impact on ecosystems and on the society at large [1-4]. Thus, climate change detection and projections based on the analysis of extreme event indices are of great importance to support studies on impacts and vulnerability and to prepare strategies to adapt to climate change. Among others, such studies have been undertaken at global and regional level by [4-12]. This detection type of study requires high-quality and longterm observed data, which are not always available.

There is consensus in most of the climate change detection studies for South America [5-7,11] concerning warming, that there is an increase (decrease) in the frequency of warm (cold) nights, and more frequent days with heavy rain in Southeast South America. However, in the states of São Paulo, Rio de Janeiro and Minas Gerais, the results concerning precipitation are not uniform, with nearby locations showing opposite trends, as shown in [9]. Thus, a detailed investigation of the be havior of extreme climate event indicators for the city of Rio de Janeiro, in the state of the same name, will be tremendously useful.

Several groups have projected future climate change by nesting regional climate models within general circulation coupled atmosphere-ocean models. The advantage of this technique, which is known as dynamic downscaling [13-18], is that it captures regional scale aspects appropriately. Important future climate change projection results with regional models for South America can be found in $[10,18-25]$. As is the case with detection studies, future climate change projections using different models and $\mathrm{CO}_{2}$ emissions scenarios point to consensus insofar as the warming projected for the late 21 st century is concerned, but are divergent in respect to rainfall outlooks.

This research project undertakes climate change detection and investigates climate change projections for the city of Rio de Janeiro by analyzing precipitation and air temperature-related observed extremes. The aim is to support vulnerability studies and adapt them to climate change scenarios. Observed extreme events trends are detected using observational data coming from two wea- 
ther stations located in the city of Rio de Janeiro. The simulations of the Eta regional model of the National Institute for Space Research (INPE) driven by the UK Met Office Hadley Centre (HadCM3) global model for the current climate (1961-1990) are compared with observational data as a prior step for the assessment of the projections generated by the same regional model for the 2011 to 2100 period.

\section{Methodology and Data}

The observational data used in this study comprise a series of maximum and minimum air temperatures and total daily rainfall of two weather stations from the Brazilian National Institute of Meteorology (INMET), located in the city of Rio de Janeiro. Despite the limitations imposed by the use of only two weather stations, these stations did not suffer from change in location. Furthermore, they are located in distinct environments, allowing for comparisons to be made of two extreme urban conditions: the Alto da Boa Vista station ( $\left.22^{\circ} 57^{\prime} 57.50^{\prime \prime} \mathrm{S} / 43^{\circ} 16^{\prime} 46.20^{\prime \prime} \mathrm{W}\right)$, which is located within a tropical forest at the Tijuca Forest National Park at an altitude of $347.1 \mathrm{~m}$; and the Santa Cruz station ( $\left.22^{\circ} 55^{\prime} 19.59^{\prime \prime} \mathrm{S} / 43^{\circ} 41^{\prime} 12.90^{\prime \prime} \mathrm{W}\right)$, positioned in the western zone of the city at an altitude of $63.0 \mathrm{~m}$ and in a region where significant urbanization has taken place (Figure 1). Unfortunately, several flaws took place in daily data collection at each station during the analyzed data period. For the Alto da Boa Vista (Santa Cruz) station, the numerous gaps in the daily rainfall data precluded the calculation of total annual rainfall in 11 (13) years, and only 30 (33) years remained for analysis, within the period ranging from $01 / 01 / 1967$ to $12 / 31 / 2007$ (01/01/1964 to $12 / 31 / 2009$ ). At Alto da Boa Vista (Santa Cruz) station the maximum number of consecutive missing years was four (six), from 1988-1991 (1993-1998).

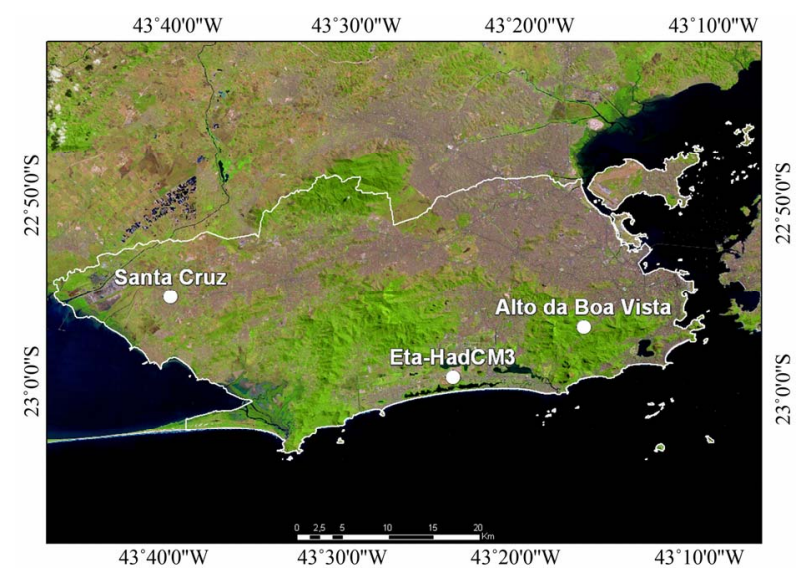

Figure 1. Map of the city of Rio de Janeiro (city border in white) showing the location of Alto da Boa Vista and Santa Cruz stations and the Eta-HadCM3 model grid point.
At INPE, the Eta-CPTEC numerical model (with a horizontal resolution of $40 \mathrm{~km}$ ), derived from the Eta regional model developed at the University of Belgrade [26], was driven by the lateral boundary conditions of the global coupled HadCM3 model [27]. For the present climate conditions (1961-1990), a $\mathrm{CO}_{2}$ concentration equal to 330 ppm was considered, while the Special Report on Emission Scenarios-SRES [28] A1B emission scenario was used for future climate (2011-2100). This study uses simulations which were generated for a set of 4 members: the control member plus 3 integrations with physical disturbances, and members with different climate sensitivities, herein referred as Ctrl, Low, Mid and High. Although the 3 members correspond to the same A1B scenario, each member's temperature increase projections are similar to the increases characteristic of scenarios of low, medium and high emissions from the IPCC SRES. Henceforth, the regional Eta model simulations integrated with the boundary conditions from the HadCM3 global model will be called Eta-HadCM3. The evaluation of the current climate and future projections of the Eta-HadCM3 model are described in $[24,25]$, respectively. The grid point of the Eta-HadCM3 model from which the series of rainfall and air temperature data were extracted lies between the two weather stations $\left(23.00^{\circ} \mathrm{S} / 43.40^{\circ} \mathrm{W}\right.$ and at an altitude of $62.9 \mathrm{~m}$ ). In Figure 1 the grid point is located in $23.00^{\circ} \mathrm{S} / 43.40^{\circ} \mathrm{W}$, representing the area $22.8^{\circ} \mathrm{S}$ $23.2^{\circ} \mathrm{S} / 43.20^{\circ} \mathrm{W}-43.60^{\circ} \mathrm{W}$.

The RClimdex software [29], developed by the Canadian Meteorological Service, was used to generate extreme climate event indicators [4] from observational data and simulations of the Eta-HadCM3 model, for the 19611990 base period. Table 1 presents the definition of the indices used in this study.

The Mann-Kendall non-parametric statistical test was used to assess the climate trends [30]. This is the most appropriate method to analyze the significance of possible climate change in climatological series [31]. One of the benefits afforded by this test is that the data doesn't have to belong to a particular distribution. Another benefit is that its result is less affected by outlier values because the calculation is based on the sign of the differences, and not directly on the values of the variables. The confidence level adopted in the Mann-Kendall statistical test was $95 \%$ for all data series. The non-parametric method called the Sen Curvature [32] was used to estimate the magnitude of the trends found in the data series.

\section{Rio de Janeiro City Climate}

The study area, the city of Rio de Janeiro, located in Southeastern Brazil, between the $22.8^{\circ}$ and $23.1^{\circ} \mathrm{S}$ parallels and the meridians of $43.1^{\circ}$ and $43.8^{\circ} \mathrm{W}$, features a warm, rainy climate in the summer and cold, dry weather in the 
Table 1. Definitions and magnitudes of the climate extremes indicators related to precipitation, maximum and minimum air temperature observed at Alto da Boa Vista and Santa Cruz. The values in boldface are considered statistically significant at a confidence level of $95 \%$. $R R$ is the daily rainfall rate. A wet day has $R R \geq 1 \mathrm{~mm}$. A dry day has $R R<1 \mathrm{~mm}$. TX and TN are daily maximum and minimum air temperature, respectively.

\begin{tabular}{|c|c|c|c|}
\hline Indicator & Definition and unity & Alto da Boa Vista & Santa Cruz \\
\hline PRCPTOT & Annual total precipitation from wet days $(\mathrm{mm})$ & $+7.83 \mathrm{~mm} /$ year & $+2.54 \mathrm{~mm} /$ year \\
\hline R95 p & $\begin{array}{l}\text { Annual total precipitation on the days when } \mathrm{RR}>95 \text { th percentile } \\
\text { of the wet days }(\mathrm{mm})\end{array}$ & $+11.77 \mathrm{~mm} /$ year & No trend \\
\hline R99 p & $\begin{array}{l}\text { Annual total precipitation on the days when } \mathrm{RR}>99 \text { th percentile } \\
\text { of the wet days }(\mathrm{mm})\end{array}$ & $+3.40 \mathrm{~mm} /$ year & No trend \\
\hline R30 mm & Annual count of days when $\mathrm{RR} \geq 30 \mathrm{~mm}$ (days) & +0.07 day/year & +0.03 day/year \\
\hline RX1 day & Annual max 1-day precipitation (mm) & $+1.04 \mathrm{~mm} /$ year & $-0.86 \mathrm{~mm} /$ year \\
\hline RX5 day & Annual max consecutive 5-day precipitation (mm) & $+1.54 \mathrm{~mm} /$ year & $-0.47 \mathrm{~mm} /$ year \\
\hline CDD & Max number of consecutive dry days in the year (days) & No trend & No trend \\
\hline CWD & Max number of consecutive wet days in the year (days) & No trend & No trend \\
\hline SU25 & Number of days with $\mathrm{TX}>25^{\circ} \mathrm{C}$ (days) & +1.42 day/year & +0.44 day/year \\
\hline TMAXmean & Annual mean of TX $\left({ }^{\circ} \mathrm{C}\right)$ & $+0.04^{\circ} \mathrm{C} /$ year & $+0.03^{\circ} \mathrm{C} /$ year \\
\hline TX90 p & Percentage of days with TX > 90th percentile (\%) & $+0.15 \%$ day/year & $+0.15 \%$ day/yea \\
\hline TX10 p & Percentage of days with TX $<10$ th percentile $(\%)$ & $-0.20 \%$ day/year & $-0.11 \% \mathrm{day} / \mathrm{year}$ \\
\hline WSDI & $\begin{array}{c}\text { Number of days in the year with at least } 6 \text { consecutive } \\
\text { days of TX }>90 \text { th percentile }\end{array}$ & +0.17 day/year & +0.02 day/year \\
\hline TMINmean & Annual mean of $\mathrm{TN}\left({ }^{\circ} \mathrm{C}\right)$ & No trend & $+0.01^{\circ} \mathrm{C} /$ year \\
\hline TN90 p & Percentage of days with $\mathrm{TN}>90$ th percentile $(\%)$ & $+0.03 \%$ day $/$ year & $+0.17 \%$ day/yeaı \\
\hline TN10 p & Percentage of days with $\mathrm{TN}<10$ th percentile $(\%)$ & $-0.03 \%$ day/year & $-0.06 \%$ day/year \\
\hline DTR & Mean of the difference between $\mathrm{TX}$ and $\mathrm{TN}\left({ }^{\circ} \mathrm{C}\right)$ & $+0.05^{\circ} \mathrm{C} /$ year & $+0.01^{\circ} \mathrm{C} /$ year \\
\hline
\end{tabular}

winter. The city is influenced by the presence of the Atlantic Ocean to the south, the Guanabara Bay to the east, and the Sepetiba Bay to the west. The city's topography is marked by the formation of three massifs: GericinóMendanha, to the north; the Tijuca massif to the east, where the Alto da Boa Vista station is located; and the Pedra Branca massif, to the west. The other areas of the city are lowlands with an average altitude of about $20 \mathrm{~m}$. The Santa Cruz station is in the West Zone lowland (Figure 1).

Although the study area is under the influence of the South Atlantic Subtropical Anticyclone during most of the year, the most frequent winds are not from the northeast. In the city, dominant winds are southerly during the afternoon and night (sea breeze) and northerly at late night and in the morning (land breeze). In spring and summer, when land surface heating is more intense, the temperature gradient between continent and ocean intensifies the sea breeze circulation and increases the frequency of winds blowing from the south quadrants compared with the annual pattern. In fall and winter, winds coming from the southerly direction are less frequent, while the northerly ones increase. In Santa Cruz, the prevailing winds are from the northeast at dawn and in the morning, while from the southwest in the afternoon and evening [33].

The spatial distribution of air temperature is influenced by the topography and by the action of sea and land breezes. The Tijuca and Pedra Branca massifs, located near the waterfront, hamper the penetration of the sea breeze and transient systems into the city, making the Northern and Western regions of the city much warmer and drier than the Southern region and the downtown area. The stations located in the Western Zone register the highest temperatures, while the Alto da Boa Vista station registers the lowest ones.

The same regional geographic features affect rainfall, with maximums concentrated along the three massifs in the city. In the Western Zone, the total annual rainfall adds up to less than $1200 \mathrm{~mm}$, while in Tijuca (where the Alto da Boa Vista station is located), it is almost double, averaging $2200 \mathrm{~mm}$. This spatial rainfall distribution pattern 
is explained by the displacement of weather systems, mainly from south to north, producing maximum (minimum) rainfall to the windward (leeward) of the mountains. The orographic lifting of moist air advected by the sea breeze further enhances this process. The analysis of heavy rainfall events (greater than $30.0 \mathrm{~mm} /$ day) indicates that in $77 \%$ of cases, the rains are caused by frontal systems that occur year-round, although less frequently in winter [34].

Based on what was stated above, it is clear that the two stations selected for this study represent very different climates, with the Alto da Boa Vista station located in a high region with low temperatures and the highest rainfall in the area, while the Santa Cruz station is in lowland, where temperatures are higher and total rainfall low. Moreover, near the Alto da Boa Vista station, as it is situated within the Tijuca Forest, the vegetation has not undergone major changes and urban sprawl has been limited in recent decades, while in areas near the Santa Cruz station there has been significant urban area densification and expansion, with possible reductions in the vegetation cover.

\section{Climate Extremes: Present and Future Climates}

The results of climate extremes on the present and future climates are presented first for rainfall, then for air temperature. Although the Eta-HadCM3 model simulations for present and future climate are on the same graph, its trends and significances are calculated separately. The ensemble of the four members of the model is used in the model's simulations for the present climate. For future climate, member averages are used for indicators based on precipitation, since no large dispersion is seen among members; meanwhile, each of the members is analyzed for temperature (Ctrl, Low, Mid and High) separately in order to explore the difference between them.

\subsection{Rainfall}

Figure 2 features the total annual rainfall (PRCPTOT) of wet days (days when rainfall is greater than or equal to 1 $\mathrm{mm}$ ) and the total annual rainfall of days when it is above the 95th percentile of wet days (R95p). Initially, a high interannual variability is noted in the observational data, especially in Alto da Boa Vista, and it is worthy of note that 1967 and 1998 were the wettest (El Niño years). There is also an increasing PRCPTOT trend for the two INMET stations. Despite the rate of $+7.83 \mathrm{~mm} /$ year for Alto da Boa Vista and of $+2.54 \mathrm{~mm} /$ year for Santa Cruz, these trends are not statistically significant at a confidence level of $95 \%$. These results agree with those obtained for Southeastern South America by [7], in which PRCPTOT shows an increase. On the other hand, negative trends in total annual precipitation were found for the State of Rio de Janeiro by [9] for Nova Friburgo in the period ranging from 1951 to 2001; [35], for Resende in the period of 1932 to 2000, and even [36] for the Capela Mayrink station (1977-2002), also located in the Tijuca massif, less than 2 $\mathrm{km}$ away from the Alto da Boa Vista station. This shows how rainfall is considerably dependent on local conditions, such as the land and sea breeze effects. As it will be discussed later, the Eta-HadCM3 model doesn't reproduce the strong interannual variability of PRCPTOT, mainly at Alto da Boa Vista station, located in a higher altitude, with heavy rainfall events. The model simulates, in the present climate, a reduction in PRCPTOT $(-6.17 \mathrm{~mm} /$ year $)$, and continues showing a slight reduction for this index in the future $(-0.39 \mathrm{~mm} /$ year $)$.

The R95p index (Figure 2) shows a statistically significant increase for Alto da Boa Vista $(+11.77 \mathrm{~mm} / \mathrm{year})$ and a null trend for Santa Cruz in the current climate. This implies that at Alto da Boa Vista either heavy rainfall events have become stronger, i.e., associated with a higher volume of rainfall each year, or they are becoming more frequent, or both. In the present climate, the regional model does not capture this increase in R95p; however, it reverts in the future and shows an increasing trend $(+1.17$ $\mathrm{mm} /$ year), which is statistically significant. The R99p index shows the same R95p behavior, i.e. positive trend for Alto da Boa Vista $(+3.40 \mathrm{~mm} /$ year $)$ and no trend for Santa Cruz (both without statistical significance). The regional model, however, indicates a slight positive trend for R99p in the current climate $(+0.19 \mathrm{~mm} /$ year-not statistically significant) and in the future scenario $(+0.73$ $\mathrm{mm}$ /year), with statistical significance.

The RX5day and RX1day indicators that show the accumulated maximum rainfall in 1 day and in 5 days, respectively, are rising only for Alto da Boa Vista and without statistical significance. In Santa Cruz, both indi-

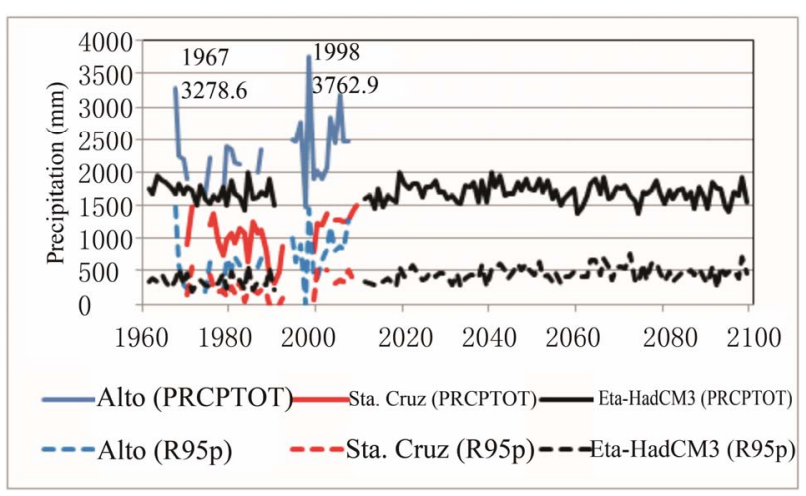

Figure 2. Temporal evolution of the PRCPTOT (solid lines) and R95 p (dashed lines) indices, both in $\mathrm{mm}$, during the present climate, observed for Alto da Boa Vista in blue and in red for Santa Cruz. The black line refers to the EtaHadCM3 model simulations (mean of the 4 members of the ensemble) for present and future climates. 
ces are in a slight decline. In general, it is noted that the current rainfall climate positive trends are more marked in Alto da Boa Vista than in Santa Cruz.

The R30 mm indicator, illustrating the number of days in the year on which the total daily rainfall was above 30 $\mathrm{mm}$, shows no statistically significant positive trends for Alto da Boa Vista (+0.07 day/year) and Santa Cruz (+0.03 day/year). In the latter, the frequency of R30 mm that occurred on average 6 times a year from 1975-1984, became on average 10 times a year in the 1998-2007 period. [37] shows that the frequency of extreme daily rainfall events ( $>100 \mathrm{~mm} /$ day) increased at the Capela Mayrink Station from 1977 to 2002 . This confirms that moderate to heavy rain events are becoming more frequent every year. In the present climate, the regional model presents a statistically non-significant negative trend for R30 mm $(-0.05$ day/year); however, this reverts in the future, with a statistically significant trend of +0.02 day/year.

The CDD and CWD indices that illustrate the maximum number of consecutive dry and wet days, respecttively, show null trends, both in Alto da Boa Vista and in Santa Cruz, and this characteristic is well represented by the Eta-HadCM3 model. For CDD, the values are close to those noticed in Alto da Boa Vista (between 12 and 33 days). A high interannual variability is noted in Santa Cruz, where CDD reaches 59 days (occurring in the 01/ 24 to $03 / 23 / 1990$ period). The regional model shows an upward trend in this index $(+0.04$ day/year) for the future, and it is statistically significant. For CWD in the future, the model projects a statistically significant trend of decline ( -0.01 day/year), i.e., reducing the duration of consecutive wet days.

The regional model simulations, with a horizontal resolution of $40 \mathrm{~km}$, cannot reproduce the high interannual variability of the extreme rainfall-related indices. Besides the patchy nature of rainfall and the influence of the topography, in the global and even in regional models, precipitation is mediated in the area and, therefore, the magnitude of the extremes is reduced compared to the values observed at the stations [38]. It has been recognized that the comparison between model grid output and station data is not straightforward [39-41] and that calculations of precipitations extremes indices could be sensitive to model resolution [42-44]. [43] notes that precipitation extremes obtained from individual station records are essentially point estimates and are not directly comparable to gridded model output that presumably represents precipitation variability on much coarse spatial scales. Nevertheless, for most of the indices that were calculated, the magnitude of the indicators was limited between the values observed in Alto da Boa Vista and in Santa Cruz, increasing the confidence in the usefulness of their future projections. Regarding the simulated trends, although most of them exhibit trends that are opposite to those that have been observed, it should be noted that there are differences even in series of observational data coming from stations that are relatively close to each other, as was the case of PRCPTOT in Alto da Boa Vista and Capela Mayrink and also of RX1 day and RX5 day, with positive trends for Alto da Boa Vista and negative ones for Santa Cruz.

\subsection{Air Temperature}

For Rio de Janeiro, the extreme event indices associated with maximum air temperature trends show more significant augmentation than those associated with the minimum air temperature, contrary to most of the studies undertaken to detect climate change in the globe $[4,6,8]$ and in South America [9-11,45]. Thus, the DTR index, that represents the daily thermal amplitude, which should be decreasing as in most locations, is rising in Rio de Janeiro, i.e., the maximum air temperature increases at a rate higher than the minimum temperature. This index is statistically significant for Alto da Boa Vista $\left(+0.05^{\circ} \mathrm{C} /\right.$ year), but not for Santa Cruz $\left(+0.01^{\circ} \mathrm{C} /\right.$ year $)$. At the Alto da Boa Vista station the maximum air temperature is increasing but the minimum temperature has no trend, while at Santa Cruz both maximum and minimum air temperature are increasing.

The TMAXmean and TMINmean indices that depict the annual average of the maximum and minimum daily air temperatures, respectively, are presented in Figure 3, with the top curves being for TMAXmean and lower ones for TMINmean. At both stations, one can notice a warming trend statistically significant in the current climate, but the upward trend is more significant for TMAXmean $\left(+0.04^{\circ} \mathrm{C} /\right.$ year in Alto da Boa Vista and $+0.03^{\circ} \mathrm{C} /$ year in Santa Cruz) than for TMINmean (no trend in Alto da

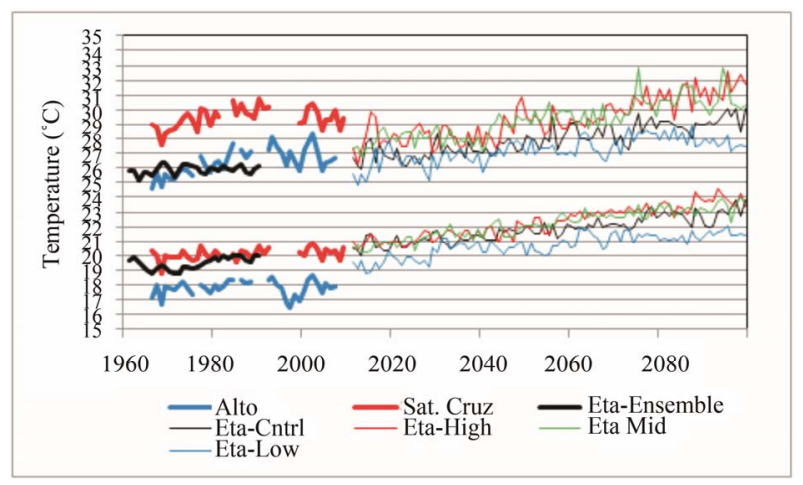

Figure 3. Temporal evolution of the TMAXmean (upper lines) and TMINmean (lower lines) indices $\left({ }^{\circ} \mathrm{C}\right)$ during the present climate, observed for Alto da Boa Vista in blue, in red for Santa Cruz, and simulated by the Eta-HadCM3 model (average of the 4 members of the ensemble) in black. For the period of 2011-2099, the fine black, blue, green and red lines refer to the Eta-Cntrl, Eta-Low, Eta-Low, Eta-Mid and Eta-High members, respectively. 
Boa Vista and $+0.01^{\circ} \mathrm{C} /$ year in Santa Cruz). The EtaHadCM3 model simulates a mild climate for Rio de Janeiro in the current climate scenario, with maximum (minimum) air temperatures near the values seen in Alto da Boa Vista (in Santa Cruz), with a positive trend of $+0.03^{\circ} \mathrm{C} /$ year for TMINmean and $+0.01^{\circ} \mathrm{C} /$ year for TMAXmean. For the late 21 st century, the model projects annual average values for maximum (minimum) air temperatures between $2^{\circ} \mathrm{C}$ and $5^{\circ} \mathrm{C}$ (between $2^{\circ} \mathrm{C}$ and $4^{\circ} \mathrm{C}$ ) above their current climatology (1961-1990).

The TX90p (warm days), shown in Figure 4, and TX10p (cold days) indices, that show the percentage of days in the year on which the maximum air temperature (TX) is, respectively, above the 90th percentile (TX > $32^{\circ} \mathrm{C}$ in Alto da Boa Vista and TX $>35^{\circ} \mathrm{C}$ in Santa Cruz) and below the 10th percentile (TX $<20.3^{\circ} \mathrm{C}$ in Alto da Boa Vista, and $\mathrm{TX}<23.4^{\circ} \mathrm{C}$ in Santa Cruz), show statistically significant trends in both locations. Hot (cold) days are becoming more (less) frequent, at a rate of $+0.15 \%$ days/year for both locations $(-0.22 \%$ days/year) for Alto da Boa Vista and $-0.11 \%$ days/year for Santa Cruz. The Eta-HadCM3 model managed to adequately capture the behaviors of such indicators in the current climate. For the late 21 st century, it has been projected that about $40 \%$ (with Eta-Low) to $70 \%$ (with Eta-High) of the days of the year will be hot and there will be no cold days for all members of the ensemble.

Although the TN90p indices (warm nights: TN > $21.5^{\circ} \mathrm{C}$ in Alto da Boa Vista and $\mathrm{TN}>23.4^{\circ} \mathrm{C}$ in Santa Cruz) and TN10p (cold nights: $\mathrm{TN}<14.0^{\circ} \mathrm{C}$ in Alto da Boa Vista and $\mathrm{TN}<16.2^{\circ} \mathrm{C}$ in Santa Cruz) show trends of an increase and a reduction, respectively, based on the observations made in Alto da Boa Vista and in Santa Cruz, they are not statistically significant (except for TN90p in Santa Cruz), as is the case for the simulation of the Eta-

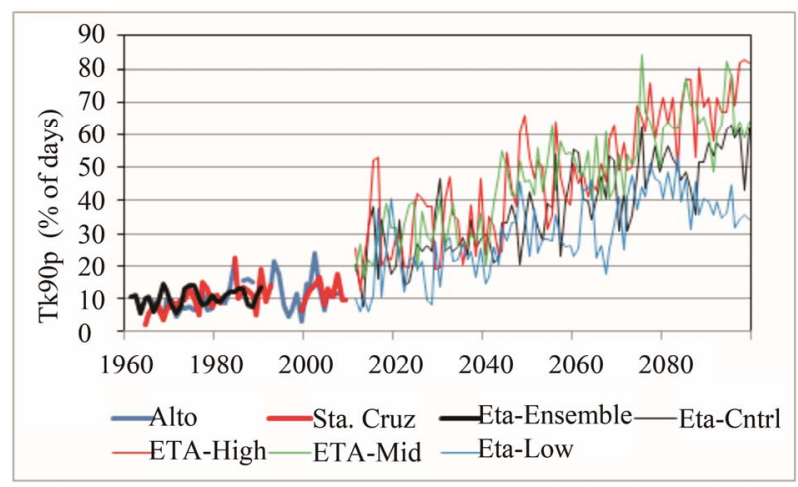

Figure 4. Temporal evolution of TX90p in a percentage of days per year, during the present climate, observed for Alto da Boa Vista in blue, for Santa Cruz in red, and simulated by the Eta-HadCM3 model (average between the 4 members of the set) in black. For the period of 2011-2099, the fine black, blue, green and red lines refer to the Eta-Cntrl, Eta-Low, Eta-Mid and Eta-High members, respectively.
HadCM3 model in the current climate. For the future climate scenario, it is projected there will be about $55 \%$ of warm nights in the year with Eta-Low and $85 \%$ with Eta-High. There will also be no cold nights in the late 21 st century.

The WSDI indicator (heat waves), which represents the maximum number of consecutive days in the year when the maximum air temperature is above the 90th percentile, shows a statistically significant positive trend for Alto da Boa Vista $(+0.17$ day/year $)$ and a weak positive trend for Santa Cruz $(+0.02$ day/year) not statistically significant. These heat waves tend to be more frequent and to last longer by the late 21 st century, as per the four members of the Eta-HadCM3 model. The control member shows that the city of Rio de Janeiro could face more than 90 consecutive days of temperatures above the 95 th percentile by 2100.

Table 1 shows a summary of the trends observed for the climate extremes indicators related to rainfall, maximum air temperature and minimum air temperature that were analyzed earlier. It is noted that trends are significant to air temperature but not for precipitation, except for R95p at Alto da Boa Vista. Besides, as interannual variability at the present climate is higher for precipitation than for temperature, the magnitudes of the differences between future and present are stronger for temperature than precipitation. According to [6] precipitation changes around the world are much less spatially coherent compared with temperature change, with large areas showing both increasing and decreasing trends.

Sea surface temperature near Rio de Janeiro state had increased 1 to 1.5 degree in the past few decades [47]. Warmer sea surface tends to evaporate more water, and sea breeze will bring more rainfalls to the city. [46] comments that generally, precipitation extremes are expected to increase in severity with climate change, and these will have adverse impacts on metropolitan region of Rio de Janeiro, given that such area already experiences extreme flooding and landslides on a roughly 20 year basis. This is consistent with the discovery of this paper for Alto da Boa Vista, located in a forested region, near the waterfront, windward of Tijuca massif. In terms of temperatures, results at Table 1 show that warm (cold) days and nights are more (less) frequent, consistent with a global warming scenario.

\section{Conclusions}

This study undertakes a climate change detection analysis for the city of Rio de Janeiro based on a series of observational data on the total daily rainfall and the maximum and minimum daily air temperatures for two INMET stations: Alto da Boa Vista and Santa Cruz. The climate 
extremes indicators are calculated as per [4]. The simulations of the regional Eta-HadCM3 model are used to investigate future projections (2011-2100) of such indices, considering the SRES-A1B scenario. The model's assessment in the current climate (1961-1990) is performed as a prior step to investigate its future projections.

The results indicate that the climate in the city of Rio de Janeiro is becoming more humid in the forested region, with heavy rainfall events producing a greater amount of rainfall. The differences in rainfall indicators in Alto da Boa Vista and in Santa Cruz, with more marked trends in the first weather station than in the second one, suggests changes in wind patterns, the circulation of sea and land breezes, and moisture transport into the city, which needs to be investigated in more detail. This trend in extreme precipitation could perhaps be related to changes in the frequency and duration of cold fronts, since most of rainfall in this region is produced by cold front penetrations. If the frequency of cold fronts increases, it will affect both places (Alto da Boa Vista and Santa Cruz), although as Alto da Boa Vista is more humid, nearest the waterfront, within a tropical forest and in a higher altitude, rainfall should be stronger there. More investigation is needed on the assessments of trends of cold fronts in the region, helping to explain changes in rainfall extremes. For the future, it is projected an increase in both the frequency and intensity of heavy rainfall events and, on the other hand, a statistically significant increase in the duration of dry periods and a reduction in the duration of humid periods. This indicates a trend of unequally distributed rainfall for the future, with longer dry periods, but, on the other hand, more frequent heavy rainfall events.

In terms of temperature, as expected one can note a warming trend in the city; however, the most remarkable trends occur for indices associated with the maximum air temperature, in opposition to the results for most of the globe, in which the minimum air temperature increases at a higher rate than maximum air temperature. Hot (cold) days are more (less) frequent. Heat waves, i.e., periods with high maximum air temperatures, are becoming longer. The trends associated with the minimum temperature are more significant in Santa Cruz than in Alto da Boa Vista. The differences in the two regions (urban and forested) may be associated with circulation changes at the synoptic scale and also on a local scale due to the urban heat island effect. Warm evenings are also more frequent, while cold nights are in decline. According to the regional model projections, the average annual maximum (minimum) air temperature anomalies can reach between $2^{\circ} \mathrm{C}$ and $5^{\circ} \mathrm{C}$ (between $2^{\circ} \mathrm{C}$ and $4^{\circ} \mathrm{C}$ ) above the current values. It is projected that about $40 \%$ to $70 \%$ of the days in the year will be hot and there will be no cold days. Similar behavior is seen for hot (cold) nights, with a frequency between $55 \%$ and $85 \%$ of warm nights in the year and without any cold nights.

In the present climate, the regional model shows air temperature results that are quite consistent with the observations made at Alto da Boa Vista and in Santa Cruz, especially for the indices based on percentiles (TN10p, TN90p, TX10p, TX90p). The model's TMAXmean (TMINmean) is close to that observed in Alto da Boa Vista (Santa Cruz), suggesting that the model simulates a milder climate for Rio de Janeiro, generating DTR values about $2^{\circ} \mathrm{C}\left(3^{\circ} \mathrm{C}\right)$ lower than those observed in Alto da Boa Vista (Santa Cruz). With respect to the precipitation simulated by the model in the current climate, most of the trends are opposite to what has been observed. However there is no consensus even among the observations expressed in this study, possibly due to the rainfall depending on local systems, such as land and sea breezes, or to the limitation of the observational data itself, with countless flaws.

With regard to the model's future projections, it is important to emphasize that the simulations only take into account the increased concentration of greenhouse gases, and not changes in land use and the urban heat island effect resulting from urban sprawl. Moreover, when it comes to regional models, the reliability of the high resolution projections depends on the quality of the lateral boundary condition, which in this study is provided by only one global model, and also on the ability of the regional model to develop realistic regional characteristics for the present climate. We have also to consider that regional model simulations, with a horizontal resolution of $40 \mathrm{~km}$, cannot reproduce the high interannual variability of the extreme rainfall-related indices [7]. It is suggested in here new downscaling experiments using more than one global model as boundary conditions, to allow for detailed uncertainty analyses.

More detailed studies to detect the possible intensification (weakening) of sea (land) breezes, in addition to analyses on the seasonal level, using other sets of observational data could contribute to increase the knowledge about climate change in the city of Rio de Janeiro.

\section{Acknowledgements}

Jose Marengo and Wanderson Luiz Silva were supported by the Brazilian National Council for Scientific and Technological Development (CNPq). Additional funding was provided by Rede-CLIMA, the National Institute of Science and Technology for Climate Change (INCT-CC), the FAPESP-Assessment of Impacts and Vulnerability to Climate Change in Brazil and strategies for Adaptation options project (Ref. 2008/58161-1), and the European Community's Seventh Framework Programme (FP7/ 2007-2013) under Grant N0. 212492: CLARIS-LPB project. We acknowledge the National Meteorological Institute (INMET) for providing their observed data. 


\section{REFERENCES}

[1] T. Karl, N. Nicholls and J. Gregory, "The Coming Climate," Scientific American, Vol. 276, 1997, pp. 54-59. doi:10.1038/scientificamerican0597-78

[2] D. Easterling, et al., "Climate Extremes: Observations, Modeling and Impacts," Science, Vol. 289, No. 5487, 2000, pp. 2068-2074. doi:10.1126/science.289.5487.2068

[3] G. Meehl, et al., "An Introduction to Trends in Extreme Weather and Climate Events: Observations, Socioeconomic Impacts, Terrestrial Ecological Impacts and Model Projections," Bulletin of the American Meteorological Society, Vol. 81, No. 3, 2000, pp. 413-416. doi:10.1175/1520-0477(2000)081<0413:AITTIE >2.3.CO :2

[4] P. Frich, et al., "Observed Coherent Changes in Climatic Extremes during the Second Half of the Twentieth Century," Climate Research, Vol. 19, No. 3, 2002, pp. 193212. doi:10.3354/cr019193

[5] L. A. Vincent, et al., "Observed Trends in Indices of Daily Temperature Extremes in South America 19602000," Bulletin of the American Meteorological Society, Vol. 18, No. 23, 2005, pp. 5011-5023.

[6] L. V. Alexander, et al., "Global Observed Changes in Daily Climate Extremes of Temperature and Precipitation," Journal of Geophysical Research, Vol. 111, No. D5, 2006, pp. 1-22. doi:10.1029/2005JD006290

[7] M. R. Haylock, et al., "Trends in Total and Extreme South American Rainfall in 1960-2000 and Links with Sea Surface Temperature," Journal of Climate, Vol. 19, No. 8, 2006, pp. 1490-1512. doi:10.1175/JCLI3695.1

[8] C. Tebaldi, K. Hayhoe, J. Arblaster and G. Meehl, "Going to the Extremes: An Intercomparison of Model-simulated Historical and Future Changes in Extreme Events," Climatic Change, Vol. 79, No. 3-4, 2006, pp. 185-211. doi:10.1007/s10584-006-9051-4

[9] G. Obregón and J. A. Marengo, "Mudanças Climáticas Globais e Seus Efeitos Sobre a Biodiversidade: Caracterização do Clima no Século XX no Brasil: Tendências de Chuvas e Temperaturas Médias e Extremas," Relatório, 2007.

[10] J. A. Marengo, R. Jones, L. M. Alves and M. C. Valverde, "Future Change of Temperature and Precipitation Extremes in South America as Derived from the PRECIS Regional Climate Modeling System," International Journal of Climatology, Vol. 29, No. 15, 2009, pp. 2241-2255. doi: $10.1002 /$ joc. 1863

[11] J. A. Marengo, M. Rusticucci, O. Penalba and M. Renom, "An Intercomparison of Observed and Simulated Extreme Rainfall and Temperature Events during the Last Half of the Twentieth Century: Part 2: Historical Trends," Climatic Change, Vol. 98, No. 3-4, 2010, pp. 509-529. doi:10.1007/s10584-009-9743-7

[12] M. Rusticcuci, J. A. Marengo, O. Penalba and M. Renom, "An Intercomparison of Model-Simulated in Extreme Rainfall and Temperature Events during the Last Half of the Twentieth Century. Part 1: Mean Values and Variability," Climatic Change, Vol. 98, No. 3-4, 2010, pp. 493508. doi:10.1007/s10584-009-9742-8
[13] R. E. Dickinson, R. M. Errico, F. Giorgi and G. T. Bates, "A Regional Climate Model for the Western US," Climate Change, Vol. 15, No. 3, 1989, pp. 383-422.

[14] F. Giorgi and T. Bates, "The Climatological Skill of a Regional Model over Complex Terrain," Monthly Weather Review, Vol. 117, No. 11, 1989, pp. 2325-2347. doi:10.1175/1520-0493(1989)117<2325:TCSOAR $>2.0 . \mathrm{C}$ $\mathrm{O} ; 2$

[15] F. Giorgi, "On the Simulation of Regional Climate Using a Limited Area Model Nested in a General Circulation Model," Journal of Climate, Vol. 3, No. 9, 1990, pp. 941963.

doi:10.1175/1520-0442(1990)003<0941:SORCUA $>2.0 . C$ $\mathrm{O} ; 2$

[16] H. Kida, T. Koide, H. Sasaki and M. Chiba, "A New Approach to Coupling a Limited Area Model with a GCM for Regional Climate Simulations," Journal of the Meteorological Society of Japan, Vol. 69, No. 6, 1991, pp. 723-728.

[17] R. G. Jones, et al., "Generating High Resolution Climate Change Scenarios Using PRECIS," Report, Met Office Hadley Centre, Exeter, 2004.

[18] J. A. Marengo, et al., "Future Change of Climate in South America in the Late Twenty-First Century: Intercomparison of Scenarios from Three Regional Climate Models," Climate Dynamics, Vol. 35, No. 6, 2009, pp. 1073-1097.

[19] R. D. Garreaud and M. Falvey, "The Coastal Winds off Western Subtropical South America in Future Climate Scenarios," International Journal of Climatology, Vol. 29, No. 4, 2008, pp. 543-554.

[20] W. R. Soares and J. A. Marengo, "Assessments of Moisture Fluxes East of the Andes in South America in a Global Warming Scenario," International Journal of Climatology, Vol. 29, No. 10, 2008, pp. 1395-1414.

[21] S. A. Solman, M. N. Nuñez and M. F. Cabré, "Regional Climate Change Experiments over Southern South America. I: Present Climate," Climate Dynamics, Vol. 30, No. 5, 2008, pp. 533-552. doi:10.1007/s00382-007-0304-3

[22] M. N. Nuñez, S. A. Solman and M. F. Cabré, "Regional Climate Change Experiments over Southern South America. II: Climate Change Scenarios in the Late TwentyFirst Century," Climate Dynamics, Vol. 32, No. 7-8, 2009, pp. 1081-1095. doi:10.1007/s00382-008-0449-8

[23] L. M. Alves and J. A. Marengo, “Assessment of Regional Seasonal Predictability Using the PRECIS Regional Climate Modeling System over South America," Theoretical and Applied Climatology, Vol. 100, No. 3-4, 2010, pp. 337-350. doi:10.1007/s00704-009-0165-2

[24] S. C. Chou, et al., "Downscaling of South America Present Climate Driven by 4-Member HadCM3 Runs," Climate Dynamics, Vol. 38, No. 3-4, 2011, pp. 635-653.

[25] J. A. Marengo, et al., "Development of Regional Future Climate Change Scenarios in South America Using the Eta CPTEC/HadCM3 Climate Change Projections: Climatology and Regional Analyses for the Amazon, São Francisco and the Parana River Basins," Submitted to Climate Dynamics, Vol. 38, No. 9-10, 2011, pp. 18291848 . 
[26] F. Mesinger, et al., "An Upgraded Version of the Eta Model," Meteorology and Atmospheric Physics, Vol. 116, No. 3-4, 2012, pp. 63-79. doi:10.1007/s00703-012-0182-Z

[27] C. Gordon, et al., "Simulation of SST, Sea Ice Extents and Ocean Heat Transport in a Version of the Hadley Centre Coupled Model without Flux Adjustments," Climate Dynamics, Vol. 16, No. ,2-3 2000, pp. 47-168. doi: $10.1007 / \mathrm{s} 003820050010$

[28] N. Nakicenovic, et al., "Special Report on Emission Scenarios," Cambridge University Press, Cambridge, 2000, p. 599.

[29] X. Zhang and F. Yang, "RClimDex (1.0)—User Manual," Climate Research Branch Environment Canada Downsview, Ontario, 2004.

[30] R. Sneyers, "Sur l'Analyse Statistique des Series Dóbservations," Vol. 192, Organisation Méteorologique Mondial, Gênevè, 1975.

[31] C. Goossens and A. Berger, "Annual and Seasonal Climatic Variations over the Northern Hemisphere and Europe during the Last Century," Annales Geophysicae, Vol. 4 No. B4, 1986, pp. 385-400.

[32] P. K. Sen, "Estimates of the Regression Coefficient Based on Kendall's Tau," Journal of American Statistics Association, Vol. 63, No. 324, 1968, pp. 379-1389.

[33] P. Jourdan, "Caracterização do Regime de Ventos Próximo à Superfície na Região Metropolitana do Rio de Janeiro," Course Completion Paper at the Geoscience Institute Department of Meteorology, Rio de Janeiro, Federal University of Rio de Janeiro, 2007.

[34] C. P. Dereczynski, J. S. Oliveira and C. O. Machado, "Climatologia da Precipitação no Município do Rio de Janeiro," Revista Brasileira de Meteorologia, Vol. 24, No. 1, 2009, pp. 24-38. doi:10.1590/S0102-77862009000100003

[35] A. S. Figueiró, "Mudanças Ambientais na Interface Floresta-Cidade e Propagação de Efeito de Borda no Maciço da Tijuca, Rio de Janeiro: Um Modelo de Vizinhança," Doctoral Thesis in Geography, Federal University of Rio de Janeiro, 2005.

[36] A. S. Figueiró and A. L. Coelho Netto, "Do Local ao Regional: Análise Comparativa de Transectos Pluviométricos em Diferentes Escalas," V Encontro Nacional da Associação Nacional de Pós Graduação em Geografia/ ANPEGE, Florianópolis, 2003.

[37] A. L. Coelho Netto, A. Avelar and R. D’orsi, "Domínio do Ecossistema da Floresta Atlântica de Encostas," In: Rio Próximos 100 Anos, O Aquecimento Global e a Cidade, Rio de Janeiro, Instituto Municipal de Urbanismo Pereira Passos, 2008.
[38] C. Chen and T. Knutson, "On the Verification and Comparison of Extreme Rainfall Indices from Climate Models," Journal of Climate, Notes and Correspondence, Vol. 21, No. 7, 2008, pp. 1605-1621. doi:10.1175/2007JCLI1494.1

[39] D. Kiktev, et al., "Comparison of Modeled and Observed Trends in Indices of Daily Climate Extremes," Journal of Climate, Vol. 16, No. 22, 2008, pp. 3560-3571. doi:10.1175/1520-0442(2003)016<3560:COMAOT $>2.0$. $\underline{\mathrm{CO} ; 2}$

[40] M. Wehner, "Predicted Twenty-First-Century Changes in Seasonal Extreme Precipitation Events in Parallel Climate Model," Journal of Climate, Vol. 17, No. 21, 2004, pp. 4281-4290. doi:10.1175/JCLI3197.1

[41] G. C. Hegerl, et al., "Detectability of Anthropogenic Changes in Annual Temperature and Precipitation Extremes," Journal of Climate, Vol. 17, No. 19, 2004, pp. 3683-3700. doi:10.1175/1520-0442(2004)017<3683:DOACIA $>2.0$.C $\mathrm{O} ; 2$

[42] J. Iorio, et al., "Effect of Model Resolution and Subgrid-Scale Physics on the Simulation of Precipitation in the Continental United States," Climate Dynamics, Vol. 23, No. 3-4, 2004, pp. 243-258. doi:10.1007/s00382-004-0440-y

[43] V. V. Kharin, et al., "Intercomparison of Near-Surface Temperature and Precipitation Extrems in AMIP-2 Simulations, Reanalyses, and Observations," Journal of Climate, Vol. 18, No. 24, 2005, pp. 5201-5223. doi:10.1175/JCLI3597.1

[44] S. Emori, et al., "Validation, Parameterization Dependence, and Future Projection of Daily Precipitation Simulated with a High-Resolution Atmospheric GCM," Geophysical Research Letters, Vol. 32, No. 6, 2005, pp. 1-4. doi:10.1029/2004GL022306

[45] J. A. Marengo and M. C. Valverde, "Caracterização do Clima no Século XX e Cenário de Mudanças de Clima para o Brasil no século XXI usando Modelos do IPCCAR4," Revista Multiciência, Campinas, Edição n. 8, 2007, Mudanças Climáticas.

[46] R. Blake, et al., "Urban Climate: Processes, Trends and Projections. Climate Change and Cities: First Assessment Report of the Urban Climate Change Research Network," Cambridge University Press, Cambridge, 2011, pp. 43-81. doi:10.1017/CBO9780511783142.009

[47] I. Zurbenko and M. Luo, "Restoration of Time-Spatial Scale in Global Temperature Data," American Journal of Climate Change, Vol. 1, No. 3, 2012, pp. 154-163. doi:10.4236/ajcc.2012.13013 